\title{
Glorification of Love and Sex in the Works of D.H. Lawrence
}

\author{
Dr. Pramod Mai Sairaha ${ }^{1}$, Brajesh Kumar Gupta ${ }^{2}$ \\ ${ }^{I}$ (Research Guide-Associate Professor, English, Pt. J.N.P.G.Degree College,Banda (U.p.) \\ / Bundelkhand University, Jhansi-U.P., India) \\ ${ }^{2}$ (Research Scholar-English, Singhania University, Jhunjhunu-Raj. India)
}

\begin{abstract}
Normally, his novels were probably very defective, which was why he was at his best artistically in his short stories. All the same, to get his full effect he needed length; and what should be stressed was the intense and complex reality of the world. He fashioned many characters in his novels after his own personality. An attempt has been made to ascertain how far Lawrence made use of his own life to form the material of his novels. Subject matter itself was anti-materialistic, increasingly outspoken in love and sex so he was prolific writer. Lawrence understood that history is not simply a matter of abstract movements, wars, revolutions, monarchies and governments, but that it is made the registered in the practices of everyday personal life. Even in sexual relationship, in the most private and intimate domain of the personal historical changes make their mark. Thus, in 'Women in Love' sexuality, marriage, family, friendship, and also work, education, art and even out relation with animals, all come under the closest of scrutiny, constituting as they do the cherished values of civilization which had thrown itself into mechanized carnage. Lawrence explored the destructive features of contemporary civilization through the evolving relationships of four major characters as they reflect upon the value of the arts, politics, economics, sexual experience, friendship and marriage.
\end{abstract}

\section{Introduction}

D. H. Lawrence's personality was, is it were a crystal of many facts? His collected works represent and extended reflection upon the dehumanizing effects of modernity and industrialization. Lawrence regarded the relationship between a man and a woman as a form of conflict, not a natural expression of harmony. His characters are not always easy to explain. But they always have a real existence. Normally, his novels were probably very defective, which was why he was at his best artistically in his short stories. All the same, to get his full effect he needed length; and what should be stressed was the intense and complex reality of the world. He fashioned many characters in his novels after his own personality. An attempt has been made to ascertain how far Lawrence made use of his own life to form the material of his novels. Subject matter itself was antimaterialistic, increasingly outspoken in love and sex so he was prolific writer. However, by the time of 'The Rainbow' and 'Women in Love', we recognize that Lawrence is now his own man and woman discover not only each other but also themselves. Lawrence's attitude to sexual relationships between men and women has changed the face of the English novel. An unsigned review published on February 25, 1932 in "Times Literary Supplement" say, "Mellors, as is well known, stands for Lawrence himself. His is not only a reflection of Lawrence's own sexual life, but his views are Lawrence's."

Lawrence's environment as a child and as a young man played an important part in conditioning the novelist of the future. The home was torn by parental conflict, and as a result Lawrence came to consider the relationship between men and women as a form of conflict and not a natural expression of harmony. That was why sex conflict assumed such a gigantic part in his novels. The over-possessive love of his mother imposed on abnormal strain and the emotions of the adolescent; and hence in his works he countered many threatened domination by women with almost hysterical violence. This early experience mad him, an antifeminist. In this philosophy of love and sex respect Lawrence is unique among English novelists. He was certainly not a sensualist but an honest man who treated the subject with greater freedom that had hither to been done, one who examined both the physical and spiritual aspect of the matter and the spiritual was generally not understood. The Oedipus complex is, as a matter of fact, one of the momentous autobiographical data to which "Sons and Lovers" is devoted but it has also been repeatedly touched upon in some of the plays of Lawrence. In the Third act of "A Collier's Friday Night, it is found that Mrs. Lambert does not approve of his son's (Ernest's) affair with Maggie Pearson and so querulously speaks to him :

“.... If Maggie Pearson's nobody else matters. It's only a laughing matter if the bread gets burnt to cinders and put on the fire. (Suddenly bursts into a glow of bitterness.) It's all very well, my son- you may talk about caring for me, but when it comes to Maggie Pearson it's very little you care for me or Nellie-or anybody else." ${ }^{2}$

In 'The Rainbow' Anna and Will's daughter Ursula never felt sorry for what she had done, she never forgave those who had done; she never forgave those who made her guilty. If he had said to her, "Why, Ursula did you trample my carefully - made bed? That would have hurt her to the quick, and she would have done anything for 
him but she was always tormented by the unreality of outside things. She was a very strong minded and self assertive woman.

"................Skrebensky walked near to Ursula, and with the same silent, intent approach put his arm round her waist, and softly, very softly, drew her to him, till his arm was hard and praised in upon her, she seemed to be carried along, locating, her feet scarce touching the ground, borne upon the firm, moving surface of his body, upon whose side she swooned, his face bent nearer to her, her head was leaned on his shoulder, she felt his warm breath on her face. Then softly, oh softly, so softly that she seemed to faint away, his lips touched her cheek, and she drifted through strands of heat and darkness." ${ }^{3}$

D.H. Lawrence was grievously affected by the fact of the Great War, and the result 'Women in Love', his most mature and profound work of fiction. In the light, or darkness, of the novel undertakes reassessment of those values and institutions by which we define ourselves as 'human' and thereby attempt to distinguish ourselves from the rest of the natural order. Lawrence understood that history is not simply a matter of abstract movements, wars, revolutions, monarchies and governments, but that it is made the registered in the practices of everyday personal life. Even in sexual relationship, in the most private and intimate domain of the personal historical changes make their mark. Thus, in 'Women in Love' sexuality, marriage, family, friendship, and also work, education, art and even out relation with animals, all come under the closest of scrutiny, constituting as they do the cherished values of civilization which had thrown itself into mechanized carnage. Lawrence explored the destructive features of contemporary civilization through the evolving relationships of four major characters as they reflect upon the value of the arts, politics, economics, sexual experience, friendship and marriage.

"Lawrence wrote about everything, what he thought, what he did, all the time, in letters to friends everywhere, in talk. Frieda complained to sisters, ex-lovers, friends about his sexuality. He did not satisfy her like as Sir Clifford did not satisfy his wife Connie because a war wound had left him impotent and paralyzed. Frieda got Lawrence into bed within a few minutes of their first meeting." 4

Lawrence's characters are not always easy to explain. But they always have a real existence. Sex loomed large in the novels of Lawrence in all its biological, psychological and metaphysical relations. He was most modern in his treatment of sex; there was nothing in him of the Victorian prudery and inhibitions. In 'The Rainbow' and its sequel the 'Women in Love', Lawrence dealt with conflicts, and sons-storms of sex, on an almost epic scale. Each one of his novels is remarkable for its free and frank treatment of sex, so much so that his 'The Rainbow' and 'Lady Chatterley's Lover' were proscribed on grounds of obscenity. In Lawrence's view the conflict between man and woman arises from the civilized woman's having become the desperate antagonist of man, drawing from him his greatest possession, his method or his masculinity and feminizing him and bringing him under the control of her will. In 'Aaron's Road', he makes one of the characters say, speaking of women in general.

"I hate her, when she knows, and when she wills. I hate her when she will make of me that which serves her desire. She may love me, she may be soft and kind to me, she may give her life to me. But why? Only because I am hers."

And again:

"Women are the very hottest hell once they get the start of you. There's nothing then won't do to you, once they've got you. Nothing they won't do to you especially if they love you.",

In the traditional novel, love is taken for granted, and the story deals with the obstacles that come in the way of love which are either overcome, or which frustrate love in the long run. But with Lawrence, love was concerned of, "In terms suggesting chemical affinities in moral, sentimental-social terms."

The sensation of lovers in actual bodily contact, or even of lovers merely in the presence of each others, are frequently described in terms of electronic phenomena. The lovers love each other but they do not know why they are simply "two life force" seeking nothing more precise or definite than vital fulfillment. In this respect Lawrence was unique among English novelists. He was certainly not sensualist but an honest man who treated the subject with greater freedom that had neither to been done, one who examined both the physical and spiritual aspect of the matter and the spiritual was generally not understood. In his masterpiece 'Sons and Lovers', Lawrence stated the thesis of his later novels; (Body v/s Spirit Conflict) Paul to Miriam;

"If people marry, they must live together as affectionate humans, who may be commonplace with each other without feeling awkward not as two souls." 8

In 'Lady Chatterley's Lover' Game keeper to Connie (Lady Chatterley)-

"I believe if man could fuck with warm hearts, and the women take it warm- heartedly, everything would come all right. It's all this cold hearted fucking that is death and idiocy.",

In the 'Lady Chatterley's Lover', The Game Keeper said, "Anything for a bit of warm - heartedness. But the women don't like it. Even you don't really like it. You like good, sharp, piercing cold - hearted fucking, and then pretending it's all sugar. Where's your tenderness for me? You are as suspicious of me as a cat is of a dog. I tell you it takes two even to be tender and warm hearted. You love fucking all right. But you want it to be 
called something grand and mysterious, just to flatter your own self importance. Your own self importance is more to you, fifty times more, than any man are being together with a man."10

Just as Lawrence represents the revolt against reason and materialism, so also he represents the revolt against the well-made novel. He shows little concern with the novel as an art form. His plot is simply the line of movement of the elemental life-force a sinuous, rapid, shifting the wave-like movement. His characters, though more often than not, vividly visualized, is not interesting in them, or for the projects they might undertake, but as centers of radiation quivering with the interchange of impulses, as the carriers of the vital life-force. His situations are simply the maladjustments, correspondences, counter-balances, of the life impulse, personified as the different characters of his novels.

D. H. Lawrence said in his book "Sex, Literature, and Censorship", "Love is the happiness of the world. But happiness is not the whole of fulfillment. Love is a coming together. But there can be no coming together without an equivalent going asunder. In love, all things unite in an oneness of joy and praise. But they could not unite unless they were previously apart. And, having united in a whole circle of unity, they can go no further in love. The motion of love, like a tide, is fulfilled in this instance; there must be ebb. So that the coming together depends on the going apart; the systole depends on the diastole; the flow depends upon the ebb. There can never be love universal and unbroken. The sea can never rise to high tide over the entire globe at once. The undisputed reign of love can never be. Because love is strictly a travelling. "It is better to travel than to arrive," somebody has said. This is the essence of unbelief. It is a belief in absolute love, when love is by nature relative. It is a belief in the means, but not in the end. It is strictly belief in force, for love is a unifying force. ,11

\section{Continued about sex-}

"It is a pity that sex is such an ugly little word. An ugly little word and really almost incomprehensible. What is sex, after all? The more we think about it the less we know. Science says it is an instinct; but what is an instinct? Apparently an instinct is an old, old habit that has become ingrained. But a habit, however old, has to have a beginning. And there is really no beginning to sex. Where life is, there it is. So sex is no "habit" that has been formed. Again, they talk of sex as an appetite, like hunger. An appetite; but for what? An appetite for propagation? It is rather absurd. They say a peacock puts on all his fine feathers to dazzle the peahen into letting him satisfy his appetite for propagation. But why should the peahen not put on fine feathers, to dazzle the peacock, and satisfy her desire for propagation? She has surely quite as great a desire for eggs and chickens as he has. We cannot believe that her sex urge is so weak that she needs all that blue splendor of feathers to rouse her. Not at all. , .12

\section{Conclusion}

However, this did not mean, as was wrongly supposed by his contemporaries, and as was still the belief of the thoughtless, that he was a mere turner out of cheap sex novels. Lawrence never tried to assimilate all his personal experiences in his novels at the cost of what Lawrence himself called "passion inspiration." He was by no means of voluptuary as he was so often depicted; rather he insisted on the sacred nature of sex, on the religious element in its consummation. Lawrence was an original and powerful genius, who had made significant contribution to the development of the English novel. His work was continuous with the richest tradition of the English novel, but at the same time his work modified that tradition by adding something new, he altered the dimensions of the English novel, and revealed its hidden possibilities. His novels were something new and not mere copies of his earlier novels. He was above all, as has been mentioned earlier, an artist in the truest sense of the term. Whenever he felt an acute artistic exigency, he unreservedly and honesty depicted even those personal events or situations in which he noticed to have been ridiculed or humiliated.

\section{References}

[1] Quoted by R. P. Draper in D. H. Lawrence: The Critical Heritage, Vikas Publication, 1970, page-286

[2] The Complete Plays of D. H. Lawrence, Heinemann, 1965, page- 523.

[3] The Rainbow: D. H. Lawrence (Surjeet Pub. 2001), page-299.

[4] Brenda Maddox, The Married Man: D. H. Lawrence, 1994, page-113-114.

[5] Sons and Lovers: D. H. Lawrence (A Critical Study by Ramji Lal), page-11.

[6] Ibid. page-12.

[7] Quoted in Raghukul Tilak: History of English Literature (Chaucer to the Present day), A Rajhans Publication (XIth ed. 2002-03) page-518.

[8] Sons and Lovers: D. H. Lawrence (A Critical Study by Ramji Lal, 2007) page-526.

[9] Lady Chatterley's Lover: Penguin Classics (2006) page-206.

[10] Ibid. page-207.

[11] Sex, Literature, and Censorship: D. H. Lawrence; Edited by Harry T. Moore, The Viking Press- New York, page-33.

[12] Ibid. page-40. 